ISSN 2072-4292

www.mdpi.com/journal/remotesensing

Article

\title{
A Simple Algorithm for Large-Scale Mapping of Evergreen Forests in Tropical America, Africa and Asia
}

\author{
Xiangming Xiao $^{1,2, *}$, Chandrashekhar M. Biradar ${ }^{1,2, *}$, Christina Czarnecki ${ }^{2}$, Tunrayo Alabi ${ }^{3}$ \\ and Michael Keller ${ }^{2,4}$
}

1 Department of Botany and Microbiology, and Center for Spatial Analysis, University of Oklahoma, Norman, OK 73019, USA

2 Institute for the Study of Earth, Oceans and Space, University of New Hampshire, Durham NH 03824, USA; E-Mail: c.czarnecki@unh.edu (C.C.)

3 International Institute of Tropical Agriculture, Ibadan, Nigeria; E-Mail: t.alabi@cgiar.org (T.A.)

4 The National Ecological Observatory Network (NEON), Boulder, CO, USA;

E-Mail: michael.keller@unh.edu (M.K.)

* Author to whom correspondence should be addressed; E-Mails: xiangming.xiao@ou.edu (X.X.); chandra.biradar@ou.edu (C.B.); Tel.: +1-405-325-8941; Fax: +1-405-325-3442

Received: 28 April 2009; in revised form: 30 May 2009 / Accepted: 3 August 2009 /

Published: 12 August 2009

Abstract: The areal extent and spatial distribution of evergreen forests in the tropical zones
are important for the study of climate, carbon cycle and biodiversity. However, frequent cloud
cover in the tropical regions makes mapping evergreen forests a challenging task. In this
study we developed a simple and novel mapping algorithm that is based on the temporal
profile analysis of Land Surface Water Index (LSWI), which is calculated as a normalized
ratio between near infrared and shortwave infrared spectral bands. The 8 -day composites of
MODIS Land Surface Reflectance data (MOD09A1) in 2001 at 500-m spatial resolution were
used to calculate LSWI. The LSWI-based mapping algorithm was applied to map evergreen
forests in tropical Africa, America and Asia ( $30^{\circ}$ N-30 S). The resultant maps of evergreen
forests in the tropical zone in 2001, as estimated by the LSWI-based algorithm, are compared
to the three global forest datasets [FAO FRA 2000, GLC2000 and the standard MODIS Land
Cover Product (MOD12Q1) produced by the MODIS Land Science Team] that are developed
through complex algorithms and processes. The inter-comparison of the four datasets shows
that the area estimate of evergreen forest from the LSWI-based algorithm fall within the range
of forest area estimates from the FAO FRA 2000 , GLC2000 and MOD12Q1 at a country level. 
The area and spatial distribution of evergreen forests from the LSWI-based algorithm is to a large degree similar to those of the MOD12Q1 produced by complex mapping algorithms. The results from this study demonstrate the potential of the LSWI-based mapping algorithm for large-scale mapping of evergreen forests in the tropical zone at moderate spatial resolution.

Keywords: MODIS image; land surface water index; temporal profile analysis; evergreen forests

\section{Introduction}

Evergreen forests (both broadleaf and needle leaf trees) in the tropical zone are an essential timber resource and play an important role in the global carbon and water cycles, biodiversity and climate. A number of efforts have been devoted to quantify the areas and spatial distributions of tropical forests [1-6]. However, frequent cloud cover in the tropical regions makes mapping evergreen forests in these zones a challenging task. In general, three research approaches have been widely used to quantify the area and spatial distribution of evergreen tropical forests at local, continental and global scales.

One approach is to compile forest inventory statistics at different administrative unit levels (county, province and nation) in a region, for example, the United Nations Food and Agriculture Organization (FAO) produced Global Forest Resources Assessments (GFRAs) in 1990, 2000 and 2005, based on forest statistics provided by individual countries [7,8].

The second approach is to map forests using satellite images at fine spatial resolution (tens of meters), e.g., Landsat TM (Thematic Mapper) and ETM+ (Enhanced Thematic Mapper). Landsat TM/ETM+ images have a spatial resolution of $30-\mathrm{m}$, and are widely used to map forests and deforestation in Amazon [9], and the globe [10]. Global-scale mapping of evergreen forests in the tropical zone from satellite images at fine resolution (e.g. Landsat TM/ETM+) is extremely challenging, because frequent cloud coverage in the moist tropical zone and infrequent image acquisition (due to the 16-day revisit interval by Landsat) often result in few cloud-free Landsat images available for analysis. Therefore, to generate a wall-to-wall coverage of Landsat TM/ETM+ images for the global tropical zone one usually needs to obtain images from several years of image acquisition by Landsat TM/ETM+ sensors.

The third approach is to map forests using satellite images at moderate spatial resolution (hundreds of meters), e.g., Advanced Very High Resolution Radiometer (AVHRR) sensors [3], SPOT-Vegetation (VGT) sensors [11] and Moderate Resolution Imaging Spectroradiometer (MODIS) sensors [4,12]. These moderate-resolution sensors acquire daily images for the globe and provide time series image data for land cover classification. The Global Land Cover Characteristics (GLCC, DIScover dataset) dataset used AVHRR data at 1-km resolution in 1992-1993 [13]. The Global Land Cover 2000 (GLC2000) dataset used the Vegetation data at $1-\mathrm{km}$ resolution in $2000[6,11,14]$. The Global Land Cover Data (MOD12Q1) used MODIS data at 1-km resolution [15]. All these data products were generated from supervised classification algorithms, which require substantial training datasets in the ground and experienced users to interpret and label spectral clusters into individual land cover types. Due to frequent cloud cover and large temporal variation of cloud cover, cloud-free time series image datasets vary significantly between years, which may have substantial impacts on the statistics of spectral clusters and 
interpretation of spectral clusters into land cover types. Although it is possible to apply these complex mapping algorithms to generate annual maps of forests, it is often time consuming and expensive, as it requires updating the training data periodically. To directly overlay two annual forest maps and then calculate annual rates of deforestation in the world is often a challenging task, because different image data sources, training datasets, and statistical algorithms are used.

Here we present a study that aims to develop a simple and novel algorithm to map the evergreen forests in the tropical world, using multi-temporal MODIS data in a year. If the simple and novel approach could produce evergreen forest maps that are similar to the forest maps from the above-mentioned complicated mapping algorithms [6,11,15], it may offer the potential for us to generate annual maps of evergreen forests in the near future, which is needed for rapid assessment of forest resources in the world.

\section{Satellite Imagery and Mapping Algorithm}

\subsection{MODIS Land Surface Reflectance Data and Vegetation Indices}

The MODIS sensor onboard the NASA Terra satellite has 36 spectral bands, and seven of these 36 bands are primarily designed for the study of vegetation and land surface: blue (459-479 nm), green $(545-565 \mathrm{~nm})$, red $(620-670 \mathrm{~nm})$, near infrared $(841-875 \mathrm{~nm}, 1,230-1,250 \mathrm{~nm})$ and shortwave infrared $(1,628-1,652 \mathrm{~nm}, 2,105-2,155 \mathrm{~nm})$. The red and NIR $(841-875 \mathrm{~nm})$ bands have a spatial resolution of 250-m, and the other five bands (blue, green, $\mathrm{NIR}_{2}, \mathrm{SWIR}_{1}, \mathrm{SWIR}_{2}$ bands) have a spatial resolution of 500-m. The MODIS sensor acquires daily imagery for the globe. The MODIS Land Science Team provides a suite of standard MODIS data products to the users, including the 8-day composite MODIS Land Surface Reflectance Product (MOD09A1). There are forty-six 8-day composites in a year. Each 8-day composite (MOD09A1) includes estimates of land surface reflectance for the seven spectral bands at 500-m spatial resolution. In the production of MOD09A1, atmospheric corrections for gases, thin cirrus clouds and aerosols are implemented [16]. MOD09A1 8-day composites are generated in a multi-step process that first eliminates pixels with a low observational coverage, and then selects an observation with highest quality during the 8-day period [17].

The MOD09A1 standard products are organized in a tile system with the Sinusoidal projection; and each tile covers an area of 1,200 × 1,200 km (approximately $10^{\circ}$ latitude $\times 10^{\circ}$ longitude at equator). In this study we acquired MOD09A1 data in 2001 (Collection 5) from the USGS EROS Data Center (EDC; http://edc.usgs.gov/); and the MOD09A1 datasets cover the tropical zone (ranging from $30^{\circ} \mathrm{N}$ to $30^{\circ} \mathrm{S}$ ). For each MOD09A1 file, the quality of individual observations (e.g., clouds, cloud shadow) was identified, and three vegetation indices are calculated: Normalized Difference Vegetation Index (NDVI, Equation 1) [18], Enhanced Vegetation Index (EVI, Equation 2) [19], and Land Surface Water Index (LSWI, Equation 3) [20], using Blue, Red, NIR 1 (841-875 nm) and SWIR $_{2}(1,628-1,652 \mathrm{~nm})$ spectral bands. The vegetation indices data products are available to the public (http://www.eomf.ou.edu).

$$
N D V I=\frac{\rho_{\text {nir }}-\rho_{\text {red }}}{\rho_{\text {nir }}+\rho_{\text {red }}}
$$




$$
\begin{gathered}
E V I=2.5 \times \frac{\rho_{\text {nir }}-\rho_{\text {red }}}{\rho_{\text {nir }}+6 \times \rho_{\text {red }}-7.5 \times \rho_{\text {blue }}+1} \\
L S W I=\frac{\rho_{\text {nir }}-\rho_{\text {swir }}}{\rho_{\text {nir }}+\rho_{\text {swir }}}
\end{gathered}
$$

The shortwave infrared (SWIR) spectral band is sensitive to vegetation water content and soil moisture [21], and a combination of NIR and SWIR bands have been used to derive water sensitive vegetation indices [22-27], including Land Surface Water Index (LSWI). LSWI is sensitive to equivalent water thickness (EWT, $\mathrm{g} \mathrm{H}_{2} \mathrm{O} / \mathrm{m}^{2}$ ) [27-29]. And recently LSWI has been used for mapping forests and agriculture [30,31], inundation [30,32], vegetation phenology [33,34], and gross primary production of forests [35].

\subsection{Temporal Profile Analysis for Identifying and Mapping Evergreen Forests}

A green leaf has higher NIR reflectance than SWIR reflectance, resulting in a LSWI value of above 0.0 (positive value). A senescent leaf and soil have lower NIR reflectance than SWIR reflectance, resulting in a LSWI value of below 0.0 (negative value). Spectral reflectance of plants and soils are well documented and reported in many hyperspectral libraries, for example, the spectral libraries in the USGS Spectroscopy Lab (http://speclab.cr.usgs.gov/) and the commercial ENVI image processing software (http://www.ittvis.com/ProductServices/ENVI.aspx). For plant leaves, LSWI $>0$ or LSWI $<0$ represents a state of change from green leaf to senescent leaf, a phenology (leaf aging process)-related change in biophysical property of leaf.

In an early study the seasonal dynamics of three vegetation indices (LSWI, NDVI and EVI) were examined for seven forest types (four deciduous broadleaf forests, one deciduous needle leaf forest, two mixed forests and one evergreen needle leaf forest) in Northeastern China [26]. LSWI values of evergreen needle leaf forest remain $>0.0$ for all good-quality satellite observations throughout a year, while all the other six forest types have some observations with LSWI values of $<0.0$ in a year [26].

Seasonal dynamics of LSWI of individual land cover types (e.g., forests, shrubs, grassland, tundra, cropland) in a year have been examined for many $\mathrm{CO}_{2}$ eddy flux tower sites in America and Asia; vegetation types at $\mathrm{CO}_{2}$ flux tower sites are well characterized [36-40]. In a previous study on an evergreen broadleaf forest in Amazon, LSWI data from both MODIS and SPOT-VEGETATION sensors remained $>0.0$ for all cloud-free observations [29]. Tropical regions have a variety of land cover types, as an example, Figure 1 shows the seasonal dynamics of LSWI of individual pixels from six land cover types (evergreen broadleaf forest, deciduous broadleaf forest, shrubland, cropland, grassland and desert) in tropical Africa. All LSWI values of the desert pixel in a year are below - 0.1, and have little seasonal variation in a year. LSWI values of evergreen broadleaf forest remain $>0.0$ for all good-quality observations throughout a year, while all the other five land cover types have a number of observations with LSWI $<0.0$ values in a year (Figure 1). Another previous study for inundated paddy rice fields, one of wetlands, have shown that paddy rice fields have a number of observations with LSWI $<0.0$ in a year, related to the post-harvest period of paddy rice fields [41]. 
Figure 1. The seasonal dynamics of Land Surface Water Index (LSWI) in 2001 from six sites that represent major land-cover types in the tropical Africa. The evergreen forest site $\left(20.9086^{\circ} \mathrm{E}, 2.3042^{\circ} \mathrm{S}\right)$ was located at the Salonga national park of Democratic Republic of Congo [IUCN/WWF (1985)]; the deciduous woodland site $\left(3.8437^{\circ} \mathrm{W}, 9.4417^{\circ} \mathrm{N}\right)$ at the Comoé National Park of Côte d'Ivoire; the savanna shrubland site $\left(2.4341^{\circ} \mathrm{E}, 11.7463^{\circ} \mathrm{N}\right)$ at the Benin National Park of Republic of Benin (http://sea.unep-wcmc.org); the cropland site $\left(8.3158^{\circ} \mathrm{E}, 12.2098^{\circ} \mathrm{N}\right)$ in Nigeria (selected from an IKONOS image of November 7,2000$)$; the savanna grassland site $\left(30.4783^{\circ} \mathrm{E}, 12.2829^{\circ} \mathrm{N}\right)$ at the $\mathrm{CO}_{2}$ flux tower site in Demokeya, Sudan (http://www.fluxnet.ornl.gov/fluxnet); and the desert site $\left(28.2478^{\circ} \mathrm{E}, 18.2083^{\circ} \mathrm{N}\right)$ in Sudan. The vegetation index data in this Figure are the original data, including cloudy observations. Cloudy observations have low NDVI values.

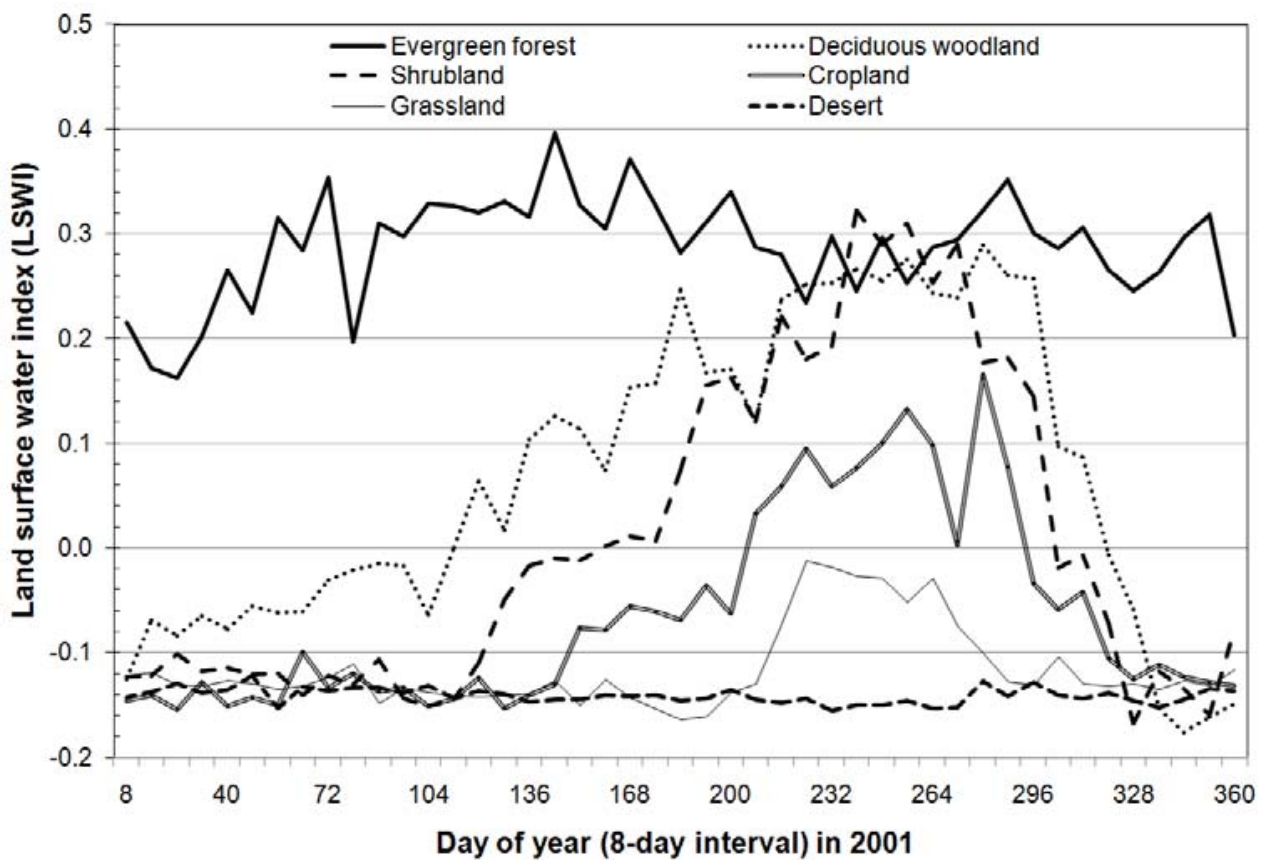

Based on this unique feature of LSWI time series data for evergreen forests (both evergreen needle leaf and broadleaf forests), we have developed a mapping algorithm/procedure to identify evergreen forest. The first step is to count number of good-quality observations that have LSWI values to be $>0.0$ in a year for a pixel. The second step is to assign a pixel that all of the good-quality observations have LSWI value of $>0.0$ to be evergreen vegetation pixel (land surface covered by green vegetation throughout a year). This yearlong green vegetation pixel could be evergreen tree (either broadleaf or needle leaf), or evergreen shrub or continuous cropping within a pixel. The third step is to examine seasonal dynamics of EVI in a year for those evergreen vegetation pixels with an aim to exclude potential commission error from evergreen shrub and continuous cropping in uplands (here we use digital elevation model of above 50-m for elevation mask.). EVI is an approximate estimate of the fraction of photosynthetically actively radiation absorbed by canopy chlorophyll (FPAR chl $)$ [29] and is used to estimate vegetation photosynthesis [35,36,42,43]. Previous studies of EVI time series of forests in Amazon showed that EVI values of evergreen tropical forests from both MODIS and SPOT-VEGETATION sensors remained larger than 0.3 throughout a year $[35,44]$. Previous studies of EVI time series of deciduous broadleaf forests in Northeast China and Northeast USA showed the EVI 
values of deciduous broadleaf forests could be $<0.20$ during the senescent to leaf-fall period [37,38]. In the third step of the mapping algorithm, we define an evergreen vegetation pixel with its minimum EVI value of $\geq 0.2$ over a year as evergreen forest. In the global implementation of the LSWI-based mapping algorithm, the vegetation indices data and quality flag data in 2001 were used to map evergreen forest in the tropical zone. The resultant dataset of evergreen forests from the LSWI-based algorithm is named as MOD100 product, simply for the purpose of differing from the names of other MODIS standard products (e.g., MOD12Q1). The resultant evergreen forest map in 2001 (MOD100) is compared with ancillary data, including other forest maps derived from more complex algorithms [15,45]. In this paper, we focus on the inter-comparison among the global forest datasets. We first compared the forest areas among the four datasets at the country level, and then carried out a spatial comparison between the MOD12Q1 and MOD100 datasets, as both of them are generated from the MODIS data.

\section{Ancillary Data for Inter-Comparison}

The following three ancillary forest datasets were used for inter-comparison in this study. A brief description of these ancillary forest datasets is given here.

\subsection{The MODIS Land Cover Product (MOD12Q1)}

The MODIS Land Science Team provides several standard MODIS-based data products, including the MODIS Land-Cover Product (MOD12Q1) [15]. For the MOD12Q1 product, the decision tree and artificial neural network classification algorithms are used with several input datasets (Table 1).

Table 1. Input datasets used in land cover classification algorithm developed for the MOD12Q1 Product [46].

\begin{tabular}{ll}
\hline Input data & Source \\
\hline Deep Water Mask & \\
Nadir BRDF-adjusted Reflectance (NBARs) & MOD43B4; MODIS Land Bands (1-7) \\
Spatial Texture (Red Band) (1-km resolution) & MODAGTEX \\
$\begin{array}{l}\text { Directional reflectance information (1-km resolution, 16-day } \\
\text { composites) }\end{array}$ & MOD43B1 \\
Enhanced Vegetation Index (EVI) (1-km resolution, 16-day & MOD13 \\
composites) & \\
Snow Cover (500-m resolution, 8-day composites) & MOD10 \\
Land Surface Temperatures (1-km resolution, 8-day composites) & MOD11 \\
Terrain elevation information & MOD03 \\
\hline
\end{tabular}

The decision tree classifier, a supervised classification method, requires the input of training sites. It uses the International Geosphere-Biosphere Programme (IGBP) Land Cover Classification System, which has 17 land cover types, including evergreen broadleaf forest and evergreen needle leaf forest. In this study we used the Collection 4 of the MOD12Q1 at 500-m spatial resolution, which was generated using MODIS data in 2001. The MOD12Q1 data are freely available to the public (http://edc.usgs.gov/). 


\subsection{The Global Land Cover 2000 (GLC2000)}

The Global Land Cover Dataset for the Year 2000 (GLC2000) was generated as a joint initiative between the European Commission Joint Research Center (JRC) and over 30 other national institutions [14], and is available to the public (http://www-gvm.jrc.it/glc2000/ProductGLC2000.htm). In the GLC2000 project, daily images acquired in the period of 1 November 1999 to December 31, 2000 by the VEGETATION (VGT) instrument onboard the SPOT4 satellite were used. The VGT sensor has four spectral bands: blue $(0.43-0.47 \mu \mathrm{m})$, red $(0.61-0.68 \mu \mathrm{m})$, NIR $(0.78-0.89 \mu \mathrm{m})$, and SWIR $(1.58-1.75 \mu \mathrm{m})$. This global daily dataset (VEGE 2000) at 1-km spatial resolution were divided into regions and distributed to more than 30 different partner institutions for land cover classification [11] . It uses the Land Cover Classification Scheme developed and used by the United Nations Food and Agriculture Organization (FAO). The accuracy assessment of the GLC2000 dataset has been documented [45], and the GLC2000 dataset has also be compared with the MODIS land cover map [47-49].

\subsection{The FAO Forest Statistics}

The FAO's Forest Resource Assessment (FRA) Program has regularly collected and provided global forest statistics since 1946. In 2002, forest statistic data was made available as a spatial dataset for the first time [7]. Several organizations coordinated with the FAO to fund and produce this dataset, including the United Nations Economic Commission for Europe (UNECE), the United Nations Environment Program (UNEP), and the U.S. Geological Survey (USGS) National Center for Earth Resources Observation and Science (EROS) in the USA. The FRA Program produced three data products: forest product, ecozones product, and protected areas product. Both the forest statistics and ecozones data products are available for download from the FAO's GeoNetwork (http://www.fao.org/geonetwork). During the 1996-1998 period, requests were made to all the countries for providing primary data regarding forest inventories and reports, which were used as a baseline for land cover assessment. In those countries where no formal inventories were available, FAO compiled information from partial inventories or secondary estimates. Of the 212 countries reported in the dataset, representatives from 160 countries actively participated in the compilation of the dataset, either through workshops or meetings with local FAO staff. The forest country statistics (FAO FRA 2000) was integrated with the Global Land Cover Characteristics Database (GLCCD) to produce the spatial maps of forests. The FAO FRA 2000 Forest map, which shows the spatial distribution of forests according to the FRA 2000 classification criteria, was generated using the source data from the 1995-1996 AVHRR data sets, and the forest map relied to a large extent on the IGBP DISCover global land cover dataset, a 1-km land cover dataset derived from Advanced Very High Resolution Radiometer (AVHRR) satellite images from April 1992 to March 1993 [13,50].

\section{Results and Discussion}

\subsection{The Area and Spatial Distribution of Evergreen Forests in Tropical America}

The LSWI-based algorithm (the MOD100 dataset) estimates a total area of $709.7 \times 10^{6}$ ha evergreen forest in tropical Central and South America $\left(30^{\circ} \mathrm{N}-30^{\circ} \mathrm{S}\right)$ in 2001 , accounting for approximately $40.4 \%$ 
of the total land area in the tropical America region (Table 2). Brazil has the largest area of evergreen forests $\left(382.5 \times 10^{6} \mathrm{ha}\right)$, followed by Peru $\left(75.1 \times 10^{6} \mathrm{ha}\right)$, Columbia $\left(69.2 \times 10^{6} \mathrm{ha}\right)$ and Venezuela $\left(42.5 \times 10^{6} \mathrm{ha}\right)$.

Table 2. Area estimates $\left(10^{3}\right.$ ha) of evergreen forests in tropical America $\left(30^{\circ} \mathrm{N}-30^{\circ} \mathrm{S}\right)$ from four spatial datasets: MOD100, MOD12Q1, FRA2000 and GLC2000.

\begin{tabular}{|c|c|c|c|c|c|c|}
\hline $\begin{array}{l}\text { Name of the } \\
\text { country }\end{array}$ & $\begin{array}{c}\text { Total } \\
\text { geographical } \\
\text { area }\left(10^{3} \text { ha }\right)\end{array}$ & $\begin{array}{c}\text { FRA } 2000 \\
\left(10^{3} \text { ha }\right)\end{array}$ & $\begin{array}{c}\text { GLC } \\
2000 \\
\left(1^{3} \text { ha }\right)\end{array}$ & $\begin{array}{c}\text { MOD12Q1 } \\
\left(1^{3} \text { ha }\right)\end{array}$ & $\begin{array}{c}\text { MOD100 } \\
\left(10^{3} \text { ha }\right)\end{array}$ & $\begin{array}{l}\text { MOD100 forest } \\
\text { to geographical } \\
\text { area (\%) }\end{array}$ \\
\hline Anguilla & 9 & 0 & 0 & 1 & 0 & 0.0 \\
\hline Antigua \& Barbuda & 54 & 6 & 15 & 6 & 0 & 0.7 \\
\hline Argentina & 89774 & 8184 & 4580 & 5930 & 3977 & 4.4 \\
\hline Barbados & 45 & 2 & 51291 & 4 & 1 & 2.2 \\
\hline Belize & 2209 & 1585 & 1247 & 1698 & 1481 & 67.0 \\
\hline Bolivia & 108661 & 41777 & 33957 & 39207 & 35369 & 32.6 \\
\hline Brazil & 836427 & 357522 & 339455 & 392987 & 382456 & 45.7 \\
\hline British Virgin Islands & 12 & 3 & 0 & 6 & 2 & 15.4 \\
\hline Cayman Islands & 21 & 10 & 0 & 8 & 11 & 50.7 \\
\hline Chile & 26973 & 1 & 3631 & 5 & 81 & 0.3 \\
\hline Colombia & 113517 & 49150 & 2004 & 71708 & 69216 & 61.0 \\
\hline Costa Rica & 5108 & 2299 & 3060 & 2980 & 3012 & 59.0 \\
\hline Cuba & 10921 & 3230 & 688 & 2260 & 1718 & 15.7 \\
\hline Dominica & 77 & 60 & 4 & 60 & 67 & 86.6 \\
\hline Dominican Republic & 4837 & 2112 & 0 & 1225 & 1530 & 31.6 \\
\hline Ecuador & 25531 & 12580 & 10511 & 15207 & 15991 & 62.6 \\
\hline El Salvador & 2057 & 833 & 301 & 373 & 187 & 9.1 \\
\hline French Guiana & 8359 & 8077 & 7854 & 8076 & 8105 & 97.0 \\
\hline Grenada & 35 & 25 & 17 & 21 & 21 & 61.0 \\
\hline Guadeloupe & 165 & 70 & 66 & 68 & 62 & 37.4 \\
\hline Guatemala & 10902 & 6331 & 4220 & 5246 & 4214 & 38.7 \\
\hline Guyana & 21059 & 17338 & 17043 & 18506 & 18586 & 88.3 \\
\hline Haiti & 2717 & 426 & 0 & 263 & 294 & 10.8 \\
\hline Honduras & 11221 & 6559 & 4632 & 5368 & 4321 & 38.5 \\
\hline Jamaica & 1104 & 552 & 0 & 642 & 732 & 66.3 \\
\hline Martinique & 115 & 38 & 1 & 52 & 66 & 57.1 \\
\hline Mexico & 176897 & 42608 & 53623 & 19365 & 13403 & 7.6 \\
\hline Montserrat & 11 & 6 & 4 & 3 & 2 & 17.7 \\
\hline Netherlands Antilles & 79 & 1 & 0 & 3 & 0 & 0.0 \\
\hline Nicaragua & 12811 & 5392 & 5879 & 5143 & 5711 & 44.6 \\
\hline Panama & 7414 & 2685 & 2988 & 4382 & 4563 & 61.5 \\
\hline Paraguay & 39881 & 2815 & 2901 & 3647 & 1870 & 4.7 \\
\hline Peru & 129086 & 58956 & 67071 & 74548 & 75077 & 58.2 \\
\hline Puerto Rico & 915 & 307 & 5 & 318 & 553 & 60.5 \\
\hline St. Kitts \& Nevis & 20 & 4 & 5 & 6 & 5 & 27.8 \\
\hline
\end{tabular}


Table 2 Cont.

\begin{tabular}{lrrrrrr}
\hline St. Lucia & 64 & 36 & 0 & 34 & 39 & 61.6 \\
St. Vincent \& the & 34 & 12 & 0 & 20 & 27 & 80.3 \\
Grenadines & & & & & \\
Suriname & 14499 & 13132 & 12927 & 13799 & 13864 & 95.6 \\
The Bahamas & 1214 & 206 & 233 & 308 & 167 & 13.7 \\
Trinidad \& Tobago & 501 & 18 & 260 & 319 & 323 & 64.4 \\
Turks \& Caicos & 30 & 3 & 0 & 13 & 9 & 28.8 \\
Islands & 91086 & 36910 & 38504 & 46237 & 42544 & 46.7 \\
Venezuela & 30 & 8 & 1 & 10 & 6 & 20.6 \\
Virgin Islands & $\mathbf{1 7 5 6 4 7 7}$ & $\mathbf{6 8 1 8 6 9}$ & $\mathbf{6 6 8 9 7 7}$ & $\mathbf{7 4 0 0 6 3}$ & $\mathbf{7 0 9 6 6 0}$ & $\mathbf{4 0 . 4}$ \\
\hline Total America & & & & & &
\end{tabular}

Among the four global forest datasets, the estimates of evergreen forests in the tropical America region ranges from $669 \times 10^{6}$ ha (the GLC2000 dataset) to $740.1 \times 10^{6}$ ha (the MOD12Q1 dataset), a magnitude of $10 \%$ difference (Table 2). The FAO FRA 2000 data estimates a total area of $681.9 \times 10^{6}$ ha evergreen forests in the tropical America region, which is about 9.6\% lower than the estimate of the MOD100 dataset (Table 2). The largest difference in a country between the MOD100 and FRA 2000 datasets occurred in Brazil $\left(\sim 25 \times 10^{6}\right.$ ha (Table 2$)$. The estimate of evergreen forests from the MOD100 dataset falls within the range of estimates as defined by the other three global datasets (FAO FRA 2000, GLC2000 and MOD12Q1) at the continental and country levels (Figure 2).

Figure 2. A comparison of evergreen forest areas in the tropical America, Africa and Asia $\left(30^{\circ} \mathrm{N}-30^{\circ} \mathrm{S}\right)$ among the four global forest datasets (MOD100, MOD12Q1, GLC2000 and FAO FRA 2000).

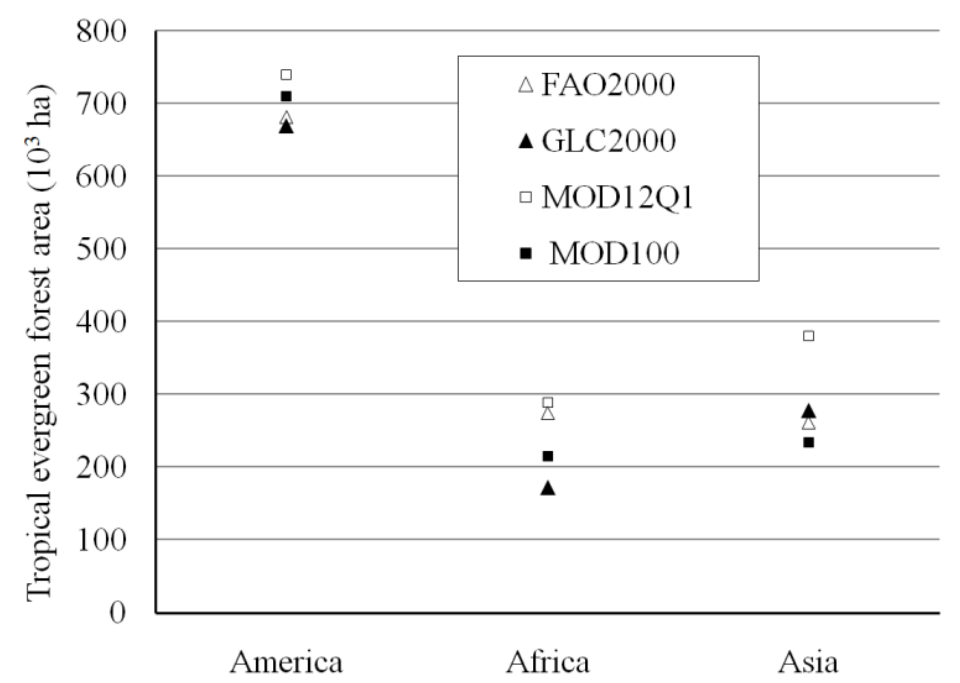

The MOD12Q1 estimates a total area of $740.1 \times 10^{6}$ ha evergreen forest in Central and South America, which is only $4.1 \%$ higher than the estimate from the MOD100. The largest difference in a country between the MOD100 and MOD12Q1 datasets (Table 2, Figure 3) occurs in Brazil ( 11.5 million ha) and Mexico ( $\sim 6$ million ha). 
Figure 3. A country-level comparison for the area estimates of evergreen forests in tropical America $\left(30^{\circ} \mathrm{N}-30^{\circ} \mathrm{S}\right)$ between the LSWI-based algorithm in this study (MOD100) and the standard MODIS Land Cover Product (MOD12Q1) in 2001.

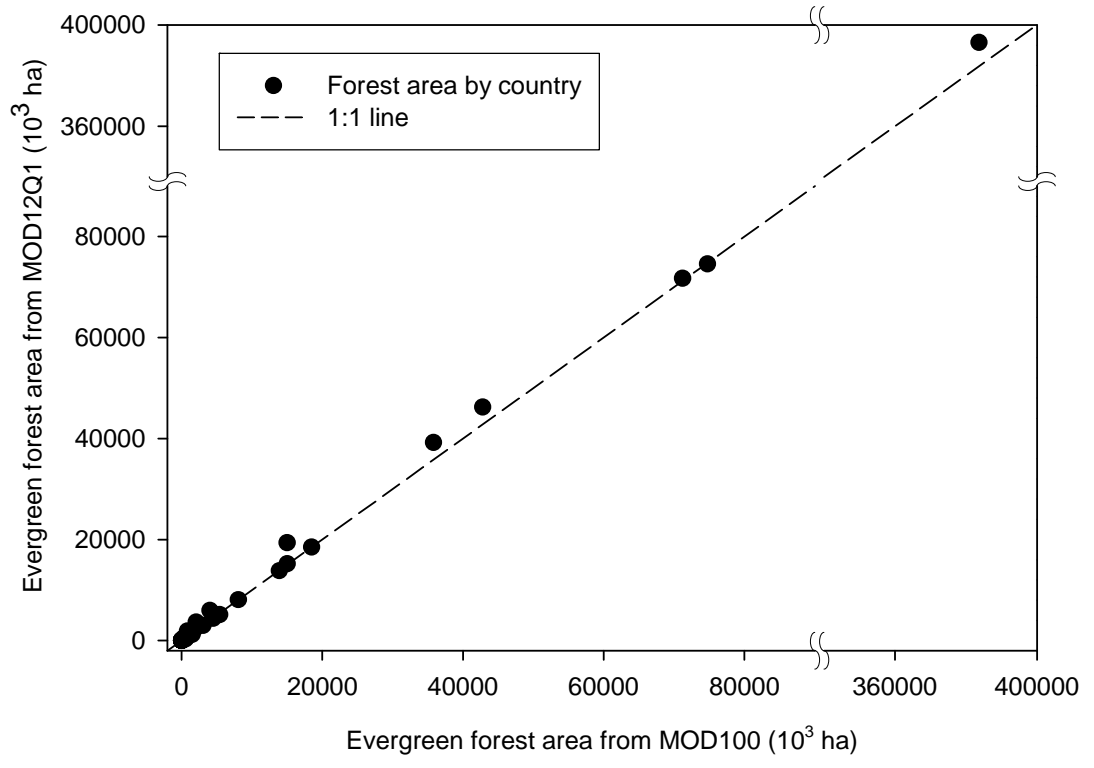

Figure 4 shows the spatial distribution of evergreen forest in tropical America as estimated by the LSWI-based algorithm (MOD100), in comparison to the MOD12Q1 dataset. The spatial pattern of evergreen forests from the MOD100 is similar to that of the standard MODIS Land Cover Product (MOD12Q1), with a spatial agreement of $84 \%$ between these two datasets (Table 5).

\subsection{The Area and Spatial Distribution of Evergreen Forests in Tropical Africa}

The LSWI-based algorithm (the MOD100 dataset) estimates a total area of $215.2 \times 10^{6}$ ha evergreen forest in tropical Africa $\left(30^{\circ} \mathrm{N}-30^{\circ} \mathrm{S}\right)$ in 2001 , accounting for approximately $9 \%$ of the total land area in the tropical Africa region. The Democratic Republic of the Congo (DRC) has the largest area of evergreen forest $\left(110.1 \times 10^{6} \mathrm{ha}\right)$, followed by Congo $\left(18.5 \times 10^{6} \mathrm{ha}\right)$, Cameroon $\left(18.4 \times 10^{6} \mathrm{ha}\right)$ and Gabon $\left(17.5 \times 10^{6} \mathrm{ha}\right)$.

Among the four global forest datasets, the estimates of evergreen forests in the tropical Africa region ranges from $171.7 \times 10^{6}$ ha (the GLC2000 dataset) to $288.7 \times 10^{6}$ ha (the MOD12Q1 dataset), a $41 \%$ difference (Table 3). It is interesting to note that the estimates of evergreen forests in Angola are $\sim 2.1 \times 10^{6}$ ha for the GLC2000 dataset, $\sim 1.6 \times 10^{6}$ ha for the MOD100 dataset, but $\sim 11.4 \times 10^{6}$ ha for the MOD12Q1dataset and $\sim 17.7 \times 10^{6}$ ha for the FAO FRA2000 data product. The large differences at country and continental scales in Africa may reflect the different reporting procedures and definitions of forests used by the African countries, as well as the difference in mapping algorithms [48]. The estimates of evergreen forests from the MOD100 dataset fall within the range of estimates as defined by the other three global datasets (FAO FRA 2000, GLC2000, and MOD12Q1) at the continental and country levels (Figure 2). 
Figure 4. Spatial distribution of evergreen forests in tropical America $\left(30^{\circ} \mathrm{N}-30^{\circ} \mathrm{S}\right)$ in $2001 \mathrm{as}$ estimated by the LSWI-based algorithm in this study (MOD100) in comparison to the MOD12Q1 dataset. In the figure legend, "Agreement" - evergreen forest pixels from both MOD100 and MOD12Q1; "MOD100" - evergreen forest pixel from MOD100 only; "MOD12Q1" - evergreen forest pixels from MOD12Q1 only. Two inserts in the figure shows a close-up comparison between these two datasets.

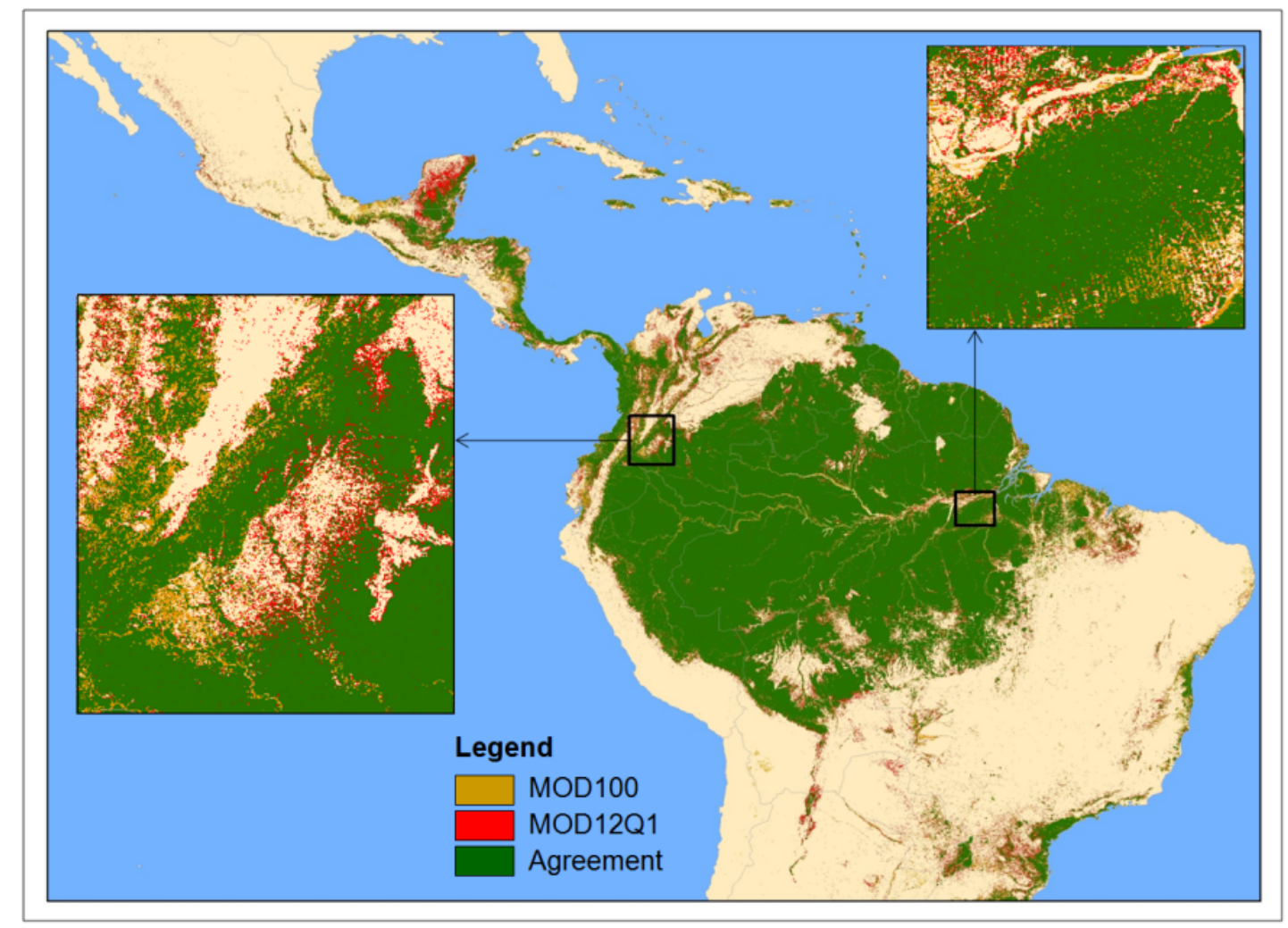

Table 3. Area estimates $\left(10^{3} \mathrm{ha}\right)$ of evergreen forests in tropical Africa $\left(30^{\circ} \mathrm{N}-30^{\circ} \mathrm{S}\right)$ from four spatial datasets: MOD100, MOD12Q1, FRA2000 and GLC2000.

\begin{tabular}{|c|c|c|c|c|c|c|}
\hline $\begin{array}{l}\text { Name of the } \\
\text { country }\end{array}$ & $\begin{array}{c}\text { Total } \\
\text { geographical } \\
\text { area }\left(10^{3} \mathrm{ha}\right)\end{array}$ & $\begin{array}{c}\text { FFRA } \\
2000 \\
\left(10^{3} \text { ha }\right)\end{array}$ & $\begin{array}{c}\text { GLC } \\
2000 \\
\left(10^{3} \text { ha }\right)\end{array}$ & $\begin{array}{c}\text { MOD12Q1 } \\
\left(10^{3} \text { ha }\right)\end{array}$ & $\begin{array}{c}\text { MOD100 } \\
\left(10^{3} \text { ha }\right)\end{array}$ & $\begin{array}{c}\text { MOD100 } \\
\text { forest to } \\
\text { geographical } \\
\text { area (\%) } \\
\end{array}$ \\
\hline Angola & 124737 & 17714 & 2114 & 11413 & 1586 & 1.3 \\
\hline Benin & 11618 & 1652 & 0 & 90 & 9 & 0.1 \\
\hline Botswana & 57834 & 30 & 0 & 52 & 5 & 0.0 \\
\hline Burkina Faso & 27234 & 731 & 0 & 61 & 0 & 0.0 \\
\hline Burundi & 2719 & 1 & 5 & 210 & 84 & 3.1 \\
\hline Cameroon & 46476 & 16079 & 18158 & 22143 & 18391 & 39.6 \\
\hline $\begin{array}{l}\text { Central African } \\
\text { Republic }\end{array}$ & 61864 & 9713 & 8171 & 7559 & 4686 & 7.6 \\
\hline Chad & 127186 & 76 & 1 & 451 & 65 & 0.1 \\
\hline Comoros & 172 & 39 & 47 & 101 & 77 & 44.8 \\
\hline Congo & 34402 & 20381 & 19247 & 23612 & 18471 & 53.7 \\
\hline Congo (DRC) & 232662 & 115560 & 85339 & 132539 & 110135 & 47.3 \\
\hline Cote d'Ivoire & 32133 & 9034 & 1244 & 9280 & 4564 & 14.2 \\
\hline
\end{tabular}


Table 3. Cont.

\begin{tabular}{|c|c|c|c|c|c|c|}
\hline Djibouti & 2144 & 0 & 0 & 2 & 0 & 0.0 \\
\hline $\begin{array}{l}\text { Equatorial } \\
\text { Guinea }\end{array}$ & 2692 & 1778 & 2031 & 2508 & 2032 & 75.5 \\
\hline Eritrea & 12090 & 2 & 0 & 3 & 1 & 0.0 \\
\hline Ethiopia & 112754 & 2835 & 323 & 4756 & 3037 & 2.7 \\
\hline Gabon & 26069 & 19399 & 22575 & 22763 & 17526 & 67.2 \\
\hline Ghana & 23904 & 3639 & 1201 & 4219 & 2644 & 11.1 \\
\hline Guinea & 24505 & 5752 & 282 & 1938 & 972 & 4.0 \\
\hline Guinea-Bissau & 3326 & 1364 & 6 & 328 & 253 & 7.6 \\
\hline Kenya & 58185 & 965 & 397 & 1601 & 1399 & 2.4 \\
\hline Lesotho & 2408 & 0 & 0 & 50 & 0 & 0.0 \\
\hline Liberia & 9600 & 5991 & 2714 & 8755 & 8015 & 83.5 \\
\hline Madagascar & 59300 & 8359 & 1434 & 9870 & 7448 & 12.6 \\
\hline Malawi & 11849 & 402 & 88 & 330 & 133 & 1.1 \\
\hline Mali & 125229 & 1916 & 1 & 52 & 12 & 0.0 \\
\hline Mauritania & 103849 & 2 & 0 & 2 & 112 & 0.1 \\
\hline Mayotte & 45 & 9 & 16 & 27 & 15 & 33.3 \\
\hline Mozambique & 78634 & 5344 & 1633 & 1490 & 729 & 0.9 \\
\hline Namibia & 82476 & 15 & 0 & 2 & 15 & 0.0 \\
\hline Niger & 118201 & 0 & 0 & 0 & 101 & 0.1 \\
\hline Nigeria & 90853 & 8374 & 2886 & 6756 & 4501 & 5.0 \\
\hline Rwanda & 2514 & 2 & 0 & 395 & 287 & 11.4 \\
\hline $\begin{array}{l}\text { Sao Tome \& } \\
\text { Principe }\end{array}$ & 114 & 0 & 25 & 83 & 69 & 60.3 \\
\hline Senegal & 19602 & 1238 & 37 & 108 & 90 & 0.5 \\
\hline Seychelles & 38 & 0 & 0 & 12 & 24 & 64.7 \\
\hline Sierra Leone & 7249 & 2455 & 352 & 3804 & 2593 & 35.8 \\
\hline Somalia & 63629 & 46 & 41 & 22 & 17 & 0.0 \\
\hline South Africa & 74514 & 503 & 389 & 1211 & 440 & 0.6 \\
\hline St. Helena & 13 & 0 & 0 & 1 & 13 & 99.2 \\
\hline Sudan & 248694 & 603 & 178 & 1709 & 298 & 0.1 \\
\hline Swaziland & 1711 & 28 & 40 & 86 & 34 & 2.0 \\
\hline Tanzania & 94139 & 3956 & 523 & 2162 & 1449 & 1.5 \\
\hline The Gambia & 1072 & 57 & 1 & 19 & 20 & 1.9 \\
\hline Togo & 5712 & 831 & 57 & 88 & 19 & 0.3 \\
\hline Uganda & 24208 & 134 & 80 & 4152 & 2555 & 10.6 \\
\hline Western Sahara & 26902 & 0 & 0 & 0 & 5 & 0.0 \\
\hline Zambia & 75192 & 6481 & 0 & 1721 & 163 & 0.2 \\
\hline Zimbabwe & 38986 & 464 & 55 & 154 & 88 & 0.2 \\
\hline Total Africa & 2391438 & 273954 & 171691 & 288690 & 215184 & 9.0 \\
\hline
\end{tabular}

The MOD12Q1 estimates a total area of $288.7 \times 10^{6}$ ha evergreen forest in Africa, which is about $34 \%$ higher than the estimate of the MOD100 dataset. The largest difference in a country between the MOD100 and MOD12Q1 (Table 3, Figure 5) occurs in Angola, approximately $9.8 \times 10^{6}$ ha (Table 2). Figure 6 shows the spatial distribution of evergreen forest in tropical Africa as estimated by the LSWI-based algorithm (MOD100), in comparison to the MOD12Q1 dataset. The spatial distribution of 
evergreen forests from MOD100 is similar to that of the MOD12Q1, with a spatial agreement of $65 \%$ between these two datasets (Table 5).

Figure 5. A country-level comparison for the area estimates of evergreen forests in tropical Africa between the LSWI-based algorithm in this study (MOD100) and the standard MODIS Land Cover Product (MOD12Q1) in 2001.

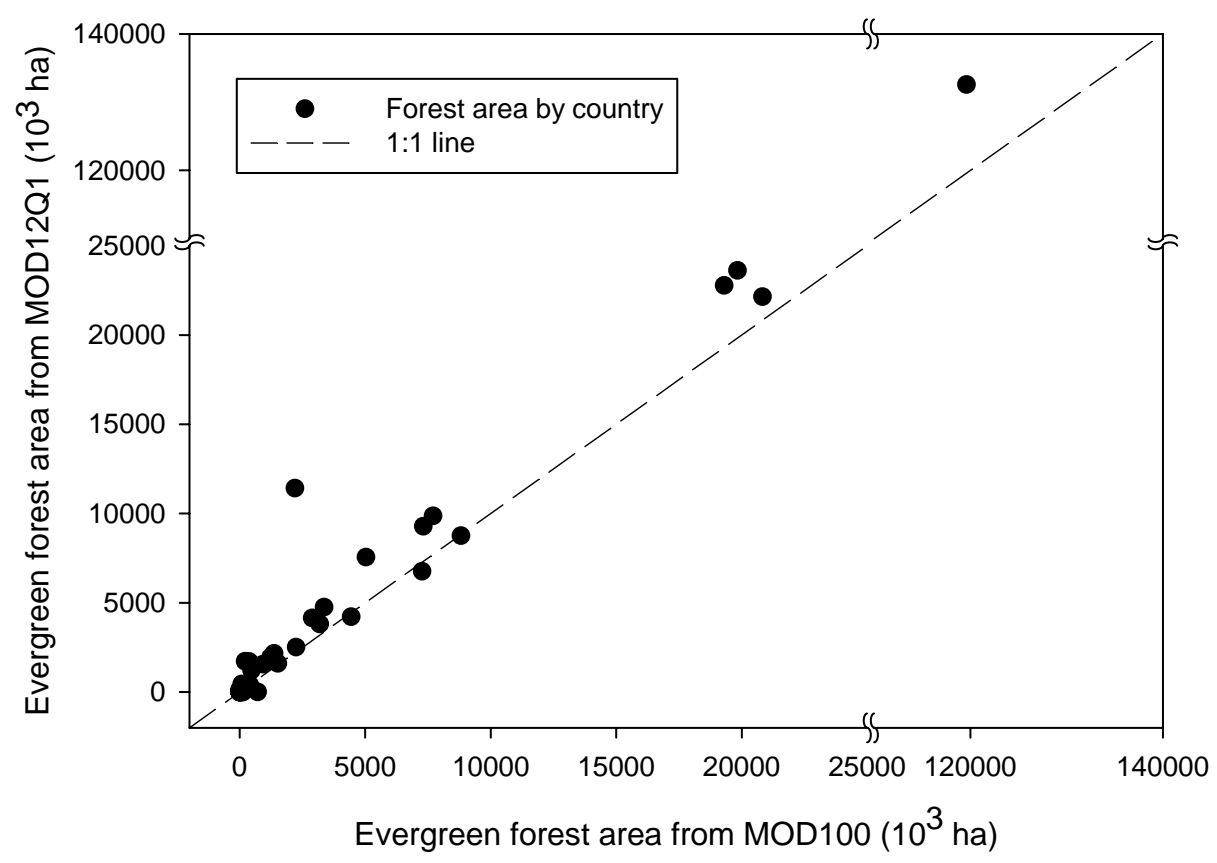

\subsection{The Area and Spatial Distribution of Evergreen Forests in Tropical Asia}

The LSWI-based algorithm (the MOD100 dataset) estimates a total area of $233.7 \times 10^{6}$ ha evergreen forest in tropical Asia $\left(30^{\circ} \mathrm{N}-30^{\circ} \mathrm{S}\right)$ in 2001 , accounting for approximately $14.5 \%$ of the total land area in the tropical Asia region. The Indonesia has the largest area of evergreen forest $\left(118.3 \times 10^{6} \mathrm{ha}\right)$, followed by Papua New Guinea $\left(31.2 \times 10^{6} \mathrm{ha}\right)$, Malaysia $\left(23.4 \times 10^{6} \mathrm{ha}\right)$ and Philippines $\left(15.2 \times 10^{6} \mathrm{ha}\right)$.

Among the four global forest datasets, the estimates of evergreen forests in the tropical Asia region ranges from $233.7 \times 10^{6}$ ha (the MOD100 dataset) to $380.6 \times 10^{6}$ ha (the MOD12Q1 dataset), a magnitude of $39 \%$ difference (Table 4). It is interesting to note that the estimates of evergreen forests in China are $3 \times 10^{6}$ ha (the FAO FRA2000 dataset), $14.6 \times 10^{6}$ ha (the MOD100 dataset), $23.7 \times 10^{6}$ ha (the MOD12Q1 dataset) and $87.9 \times 10^{6}$ ha (the GLC2000 dataset), respectively. The large differences among the four datasets may reflect the reporting procedure and definition of forests used by the Asian countries, as well as the difference in mapping algorithms [48]. Agricultural intensification (double to triple cropping in a year over cropland) in Asia is substantially higher than Africa and America; and large areas of multiple cropping area in Asia, which was reported in an earlier study [51], is likely to affect the results of the MOD12Q1 algorithms. The difference in the estimates of evergreen forests between the MOD100 dataset and the FAO FRA2000 dataset $\left(261.2 \times 10^{6}\right.$ ha) is approximately $\sim 11 \%$, largely attributed to the discrepancies in India, Myanmar and Philippine (Table 4). In the FAO FRA 2000 dataset, India and Myanmar are likely to over-report the area of evergreen forests, but Philippine may under-report the area of evergreen forests. 
Figure 6. Spatial distribution of evergreen tropical forests in tropical Africa $\left(30^{\circ} \mathrm{N}-30^{\circ} \mathrm{S}\right)$ in 2001 as estimated by the LSWI-based algorithm in this study (MOD100) in comparison to the MOD12Q1 dataset. In the figure legend, "Agreement" - evergreen forest pixels from both MOD100 and MOD12Q1; "MOD100" - evergreen forest pixel from MOD100 only; "MOD12Q1" - evergreen forest pixels from MOD12Q1 only. Two inserts in the figure shows a close-up comparison between these two datasets.

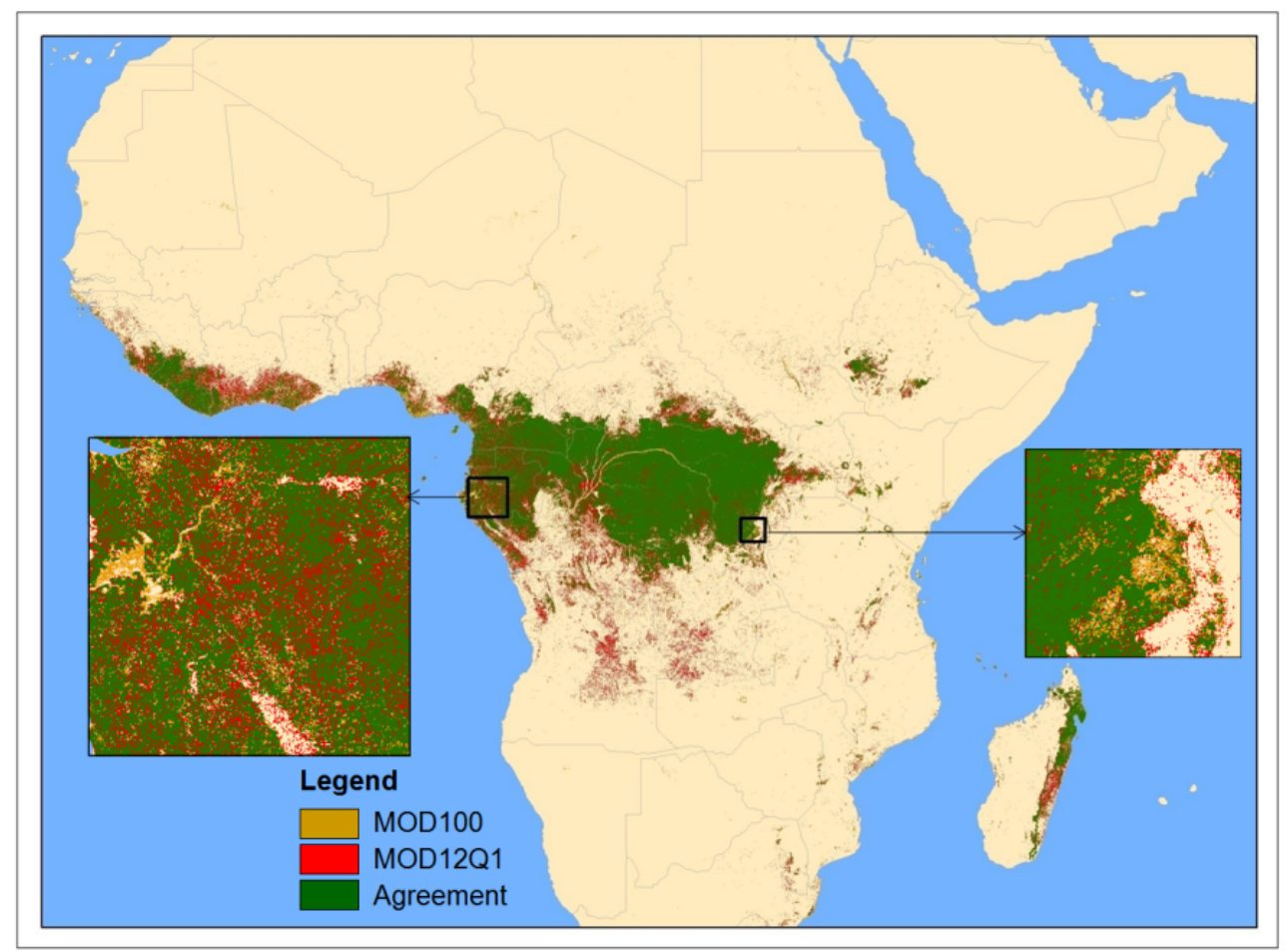

Figure 7. A country-level comparison for the area estimates of evergreen forests in tropical Asia between the LSWI-based algorithm in this study (MOD100) and the standard MODIS Land Cover Product (MOD12Q1) in 2001.

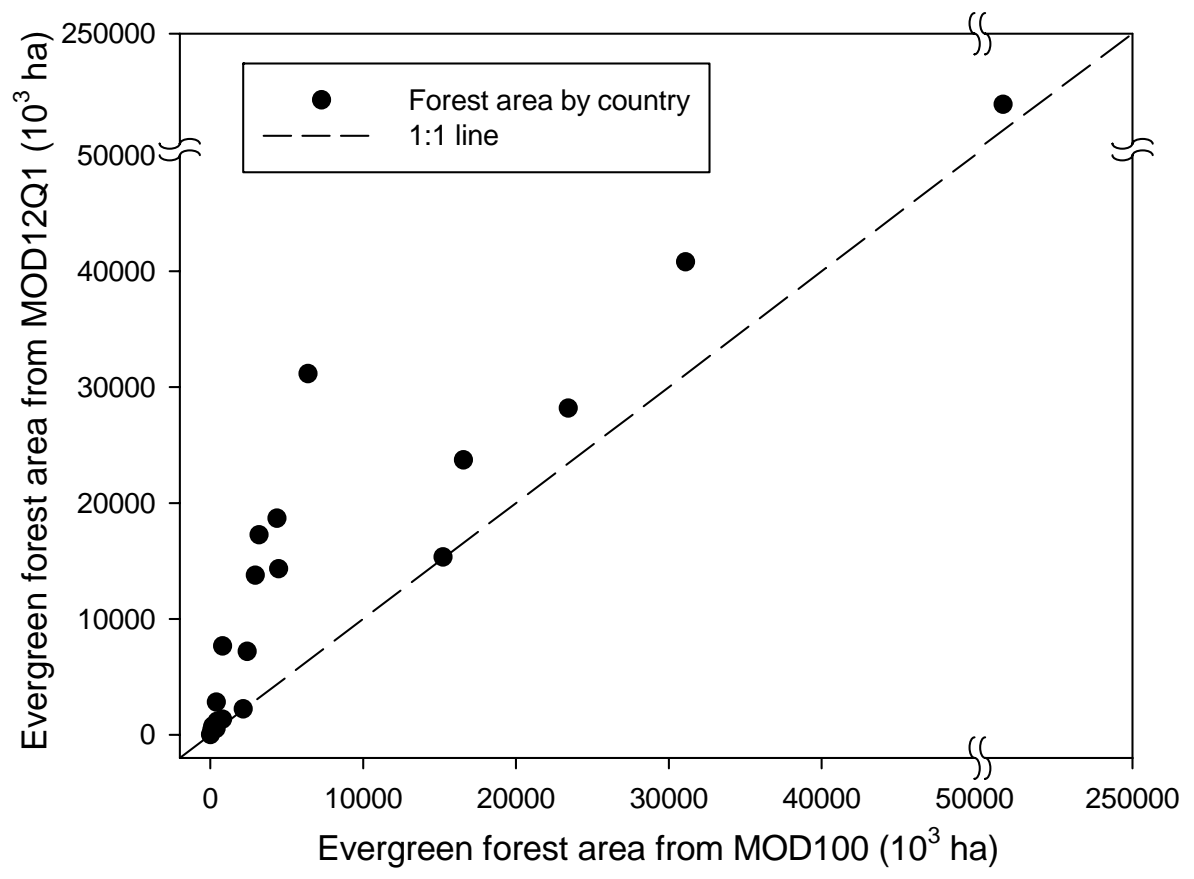


The MOD12Q1 dataset estimates a total area of $380.6 \times 10^{6}$ ha evergreen forest in the tropical Asia region, which is about $39 \%$ higher than the estimate of the MOD100 dataset. The largest difference in a country between the MOD100 and MOD12Q1 datasets occurs in Indonesia, approximately $35 \times 10^{6}$ ha (Table 4, Figure 7). Figure 8 shows the spatial distribution of evergreen forest in tropical Asia as estimated by the LSWI-based algorithm (the MOD100 dataset), in comparison to the MOD12Q1 dataset. The spatial distribution of evergreen forests from MOD100 is similar to that of MOD12Q1 dataset, with a spatial agreement of $68 \%$ between these two datasets (Table 5).

Figure 8. Spatial distribution of evergreen forests in tropical Asia $\left(30^{\circ} \mathrm{N}-30^{\circ} \mathrm{S}\right)$ in $2001 \mathrm{as}$ estimated by the LSWI-based algorithm in this study (MOD100) in comparison to the MOD12Q1 dataset. In the figure legend, "Agreement" - evergreen forest pixels from both MOD100 and MOD12Q1; "MOD100" - evergreen forest pixel from MOD100 only; "MOD12Q1" - evergreen forest pixels from MOD12Q1 only. Two inserts in the figure shows a close-up comparison between these two datasets.

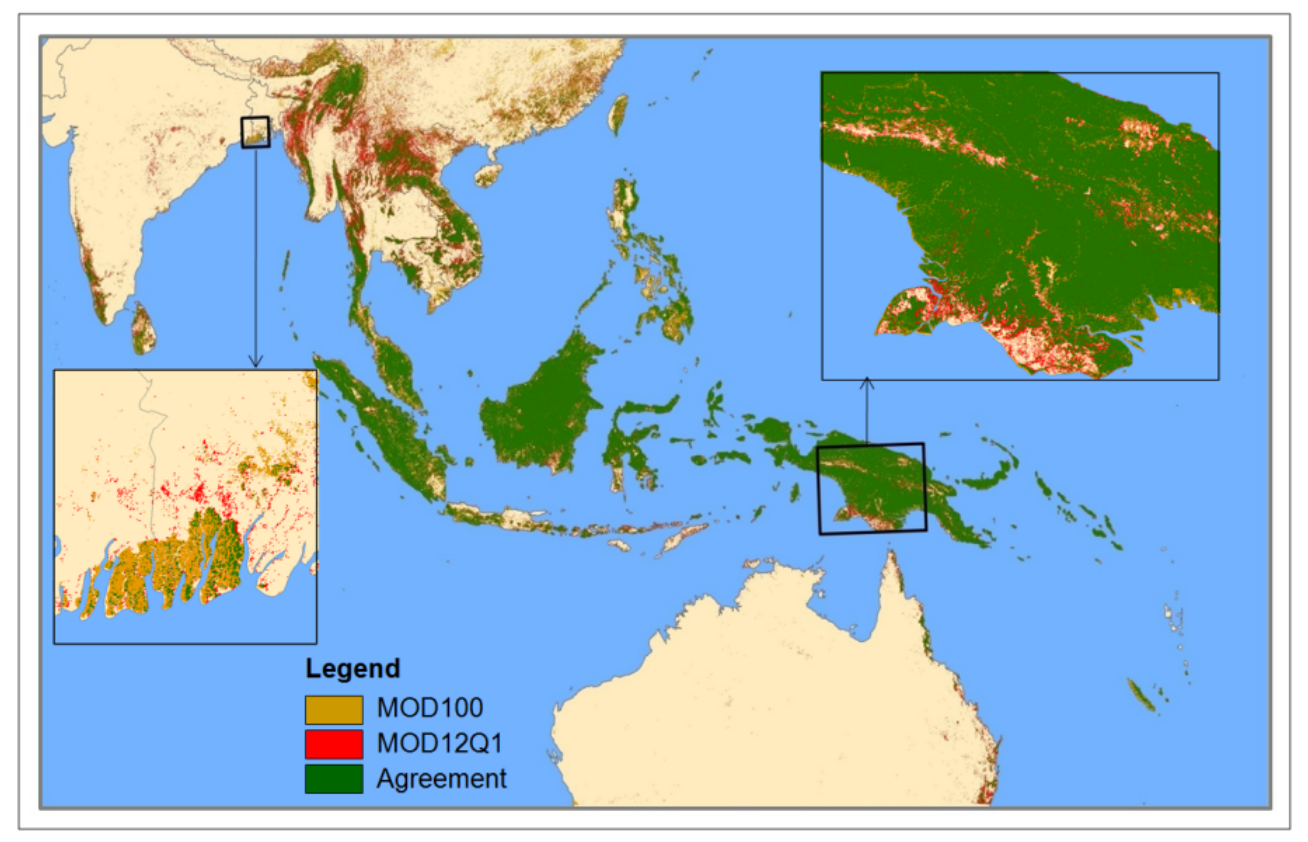

Table 4. Area estimates $\left(10^{3} \mathrm{ha}\right)$ of evergreen forests in tropical Asia $\left(30^{\circ} \mathrm{N}-30^{\circ} \mathrm{S}\right)$ from four spatial datasets: MOD100, MOD12Q1, FRA2000 and GLC2000.

\begin{tabular}{|c|c|c|c|c|c|c|}
\hline $\begin{array}{l}\text { Name of the } \\
\text { country }\end{array}$ & $\begin{array}{c}\text { Total } \\
\text { geographical } \\
\text { area }\left(1^{3} \mathrm{ha}\right)\end{array}$ & $\begin{array}{c}\text { FRA } \\
2000 \\
\left(10^{3} \text { ha }\right)\end{array}$ & $\begin{array}{c}\text { GLC } \\
2000 \\
\left(10^{3} \text { ha }\right)\end{array}$ & $\begin{array}{c}\text { MOD12Q1 } \\
\left(10^{3} \text { ha }\right)\end{array}$ & $\begin{array}{c}\text { MOD100 } \\
\left(10^{3} \text { ha }\right)\end{array}$ & $\begin{array}{c}\text { MOD100 } \\
\text { forest to } \\
\text { geographical } \\
\text { area (\%) }\end{array}$ \\
\hline Australia & 576175 & 11409 & 3519 & 7654 & 807 & 0.1 \\
\hline Bangladesh & 13788 & 1079 & 407 & 1157 & 459 & 3.3 \\
\hline Bhutan & 3984 & 2062 & 464 & 1332 & 802 & 20.1 \\
\hline Brunei & 575 & 464 & 349 & 530 & 394 & 68.5 \\
\hline Cambodia & 18174 & 6706 & 3909 & 7191 & 2417 & 13.3 \\
\hline China & 208109 & 2985 & 87915 & 23701 & 14566 & 7.0 \\
\hline India & 290417 & 34039 & 4371 & 18671 & 4355 & 1.5 \\
\hline
\end{tabular}


Table 4. Cont.

\begin{tabular}{lrrrrrr}
\hline Indonesia & 187876 & 90742 & 93121 & 153364 & 118262 & 62.9 \\
Laos & 22989 & 11827 & 4132 & 17243 & 3188 & 13.9 \\
Malaysia & 32850 & 15920 & 17813 & 28166 & 23425 & 71.3 \\
Myanmar & 66706 & 26553 & 13162 & 31160 & 6393 & 9.6 \\
Nepal & 14335 & 3103 & 1 & 734 & 159 & 1.1 \\
Papua New & & & & & & \\
Guinea & 46204 & 31639 & 29025 & 40792 & 31092 & 67.3 \\
Philippines & 29241 & 4164 & 7249 & 15336 & 15236 & 52.1 \\
Singapore & 55 & 0 & 2 & 10 & 22 & 39.7 \\
Solomon Is. & 2698 & 2250 & 1957 & 2229 & 2160 & 80.1 \\
Sri Lanka & 6604 & 1375 & 838 & 2805 & 401 & 6.1 \\
Thailand & 51228 & 6135 & 4443 & 14309 & 4473 & 8.7 \\
Timor Leste & 1504 & 164 & 169 & 463 & 106 & 7.1 \\
Vietnam & 32428 & 8538 & 5170 & 13761 & 2941 & 9.1 \\
\hline Total & $\mathbf{1 6 0 5 9 3 9}$ & $\mathbf{2 6 1 1 5 5}$ & $\mathbf{2 7 8 0 1 6}$ & $\mathbf{3 8 0 6 0 6}$ & $\mathbf{2 3 1 6 5 9}$ & $\mathbf{1 4 . 4}$ \\
\hline
\end{tabular}

Table 5. A summary of spatial comparison between MOD100 and MOD12Q1 datasets at the scale of continent and the entire tropical zone $\left(30^{\circ} \mathrm{N}-30^{\circ} \mathrm{S}\right)$.

\begin{tabular}{lrrrrrrrr}
\hline & America & \% & Africa & \% & Asia & \% & World & \% \\
\hline MOD100 & 2446968 & 7 & 903025 & 6 & 2839807 & 14 & 6189800 & 9 \\
MOD12Q1 & 3515233 & 10 & 4001688 & 28 & 3789844 & 18 & 11306765 & 16 \\
Agreement & 30617252 & 84 & 9295988 & 65 & 13961799 & 68 & 53875039 & 75 \\
\hline Total & 36579453 & 100 & 14200701 & 100 & 20591450 & 100 & 71371604 & 100 \\
\hline
\end{tabular}

\section{Summary}

In this paper, we have reported a simple and novel algorithm for mapping evergreen forests in the tropical zone; the advantage of the LSWI-based temporal profile analysis is that it does not require a large number of training datasets (including Landsat TM/ETM+ images). The LSWI-based algorithm was applied to quantify the area and spatial distribution of evergreen forests in 2001 in tropical America, Africa, and Asia, using the MODIS data at 500-m spatial resolution and 8-day temporal resolution. The areal extent and spatial distribution of evergreen forests in tropical Africa, America, and Asia from this LSWI-based mapping algorithm are similar to those of the standard MODIS Land Cover Product (MOD12Q1) that was generated from complex mapping algorithms [15], although there are large discrepancies in Asia and Africa. The inter-comparison among the four datasets showed that the areal estimates of evergreen forests from the LSWI-based MOD100 dataset falls within the range of areal estimates from the other three global data products (FAO FRA 2000, GLC2000 and MOD12Q1) that have underwent accuracy assessment $[15,45]$. The inter-comparison of global land cover data sets is a challenging task [48], given the fact that different image data sources, training datasets, and algorithms have been used in generating these global forest datasets. The results from the inter-comparison of the four global forest datasets in the tropical zone suggested the potential of this LSWI-based mapping algorithm for identifying and mapping evergreen forests in the tropical zone. The implication of this 
study is that this LSWI-based mapping algorithm might be useful for operational monitoring of evergreen forests in the tropical world at moderate spatial resolution.

\section{Acknowledgements}

This study was supported by NASA Interdisciplinary Science program (NAG5-10135, NNX07AH32G), NASA Terrestrial Ecology program (Large-scale Biosphere-Atmosphere Experiment in Amazon; NNG05GE28A), and NASA Land Use and Land Cover Change Program (NNX09AC39G), US National Institutes of Health (1R01TW007869), and the Wildlife Conservation Society in New York, USA.

\section{References and Notes}

1. Tucker, C.J.; Townshend, J.R.G.; Goff, T.E. African land-cover classification using satellite data. Science 1985, 227, 369-375.

2. Laporte, N.T.; Goetz, S.J.; Justice, C.O.; Heinicke, M. A new land cover map of central Africa derived from multi-resolution, multi-temporal AVHRR data. Int. J. Remote Sens. 1998, 19, 3537-3550.

3. Stone, T.A.; Schlesinger, P.; Houghton, R.A.; Woodwell, G.M. A map of the vegetation of South America based on satellite imagery. Photogramm. Eng. Remote Sens. 1994, 60, 541-551.

4. Hansen, M.C.; Townshend, J.R.G.; Defries, R.S.; Carroll, M. Estimation of tree cover using MODIS data at global, continental and regional/local scales. Int. J. Remote Sens. 2005, 26, 4359-4380.

5. Hansen, M.C.; DeFries, R.S. Detecting long-term global forest change using continuous fields of tree-cover maps from 8-km advanced very high resolution radiometer (AVHRR) data for the years 1982-99. Ecosystems 2004, 7, 695-716.

6. Eva, H.D.; Belward, A.S.; De Miranda, E.E.; Di Bella, C.M.; Gond, V.; Huber, O.; Jones, S.; Sgrenzaroli, M.; Fritz, S. A land cover map of South America. Glob. Change Biol. 2004, 10, 731-744.

7. FAO. Global Forest Resources Assessment 2000; Food and Agriculture Organization of the United Nations: Rome, Italy, 2001; p. 511.

8. FAO. Global Forest Resources Assessment 2005; Food and Agriculture Organization of the United Nations: Rome, Italy, 2005.

9. Skole, D.; Tucker, C. Tropical deforestation and habitat fragmentation in the Amazon - Satellite data from 1978 to 1988 (Vol 260, Pg 1909, 1993). Science 1993, 261, 1104-1104.

10. Achard, F.; Eva, H.D.; Stibig, H.J.; Mayaux, P.; Gallego, J.; Richards, T.; Malingreau, J.P. Determination of deforestation rates of the world's humid tropical forests. Science 2002, 297, 999-1002.

11. Mayaux, P.; Bartholome, E.; Fritz, S.; Belward, A. A new land-cover map of Africa for the year 2000. J. Biogeogr. 2004, 31, 861-877.

12. Hansen, M.C.; DeFries, R.S.; Townshend, J.R.G.; Sohlberg, R.; Dimiceli, C.; Carroll, M. Towards an operational MODIS continuous field of percent tree cover algorithm: examples using AVHRR and MODIS data. Remote Sens. Environ. 2002, 83, 303-319. 
13. Loveland, T.R.; Belward, A.S. The IGBP-DIS global $1 \mathrm{~km}$ land cover data set, DISCover: first results. Int. J. Remote Sens. 1997, 18, 3291-3295.

14. Bartholome, E.; Belward, A.S. GLC2000: a new approach to global land cover mapping from Earth observation data. Int. J. Remote Sens. 2005, 26, 1959-1977.

15. Friedl, M.A.; McIver, D.K.; Hodges, J.C.F.; Zhang, X.Y.; Muchoney, D.; Strahler, A.H.; Woodcock, C. E.; Gopal, S.; Schneider, A.; Cooper, A.; Baccini, A.; Gao, F.; Schaaf, C. Global land cover mapping from MODIS: algorithms and early results. Remote Sens. Environ. 2002, 83, 287-302.

16. Vermote, E.F.; Vermeulen, A. Atmospheric correction algorithm: Spectral reflectance (MOD09), MODIS Algorithm Technical Background Document, version 4.0; University of Maryland: College Park, MA, USA, 1999; p 107.

17. Vermote, E.F.; El Saleous, N.Z.; Justice, C.O. Atmospheric correction of MODIS data in the visible to middle infrared: first results. Remote Sens. Environ. 2002, 83, 97-111.

18. Tucker, C.J. Red and photographic infrared linear combinations for monitoring vegetation. Remote Sens. Environ. 1979, 8, 127-150.

19. Huete, A.R.; Liu, H.Q.; Batchily, K.; vanLeeuwen, W. A comparison of vegetation indices over a global set of TM images for EOS-MODIS. Remote Sens. Environ. 1997, 59, 440-451.

20. Xiao, X.; Boles, S.; Frolking, S.; Salas, W.; Moore, B.; Li, C.; He, L.; Zhao, R. Observation of flooding and rice transplanting of paddy rice fields at the site to landscape scales in China using VEGETATION sensor data. Int. J. Remote Sens. 2002, 23, 3009-3022.

21. Tucker, C.J. Remote-sensing of Leaf Water-Content in the near-infrared. Remote Sens. Environ. 1980, 10, 23-32.

22. Xiao, X.M.; Zhang, Q.Y.; Braswell, B.; Urbanski, S.; Boles, S.; Wofsy, S.; Moore, B.; Ojima, D. Modeling gross primary production of temperate deciduous broadleaf forest using satellite images and climate data. Remote Sens. Environ. 2004, 91, 256-270.

23. Ceccato, P.; Flasse, S.; Gregoire, J.M. Designing a spectral index to estimate vegetation water content from remote sensing data - Part 2. Validation and applications. Remote Sens. Environ. 2002, 82, 198-207.

24. Ceccato, P.; Flasse, S.; Tarantola, S.; Jacquemoud, S.; Gregoire, J.M. Detecting vegetation leaf water content using reflectance in the optical domain. Remote Sens. Environ. 2001, 77, 22-33.

25. Ceccato, P.; Gobron, N.; Flasse, S.; Pinty, B.; Tarantola, S. Designing a spectral index to estimate vegetation water content from remote sensing data: Part 1 - Theoretical approach. Remote Sens. Environ. 2002, 82, 188-197.

26. Xiao, X.; Boles, S.; Liu, J.; Zhuang, D.; Liu, M. Characterization of forest types in Northeastern China, using multi-temporal SPOT-4 VEGETATION sensor data. Remote Sens. Environ. 2002, 82, 335-348.

27. Chen, D.Y.; Huang, J.F.; Jackson, T.J., Vegetation water content estimation for corn and soybeans using spectral indices derived from MODIS near- and short-wave infrared bands. Remote Sens. Environ. 2005, 98, 225-236.

28. Maki, M.; Ishiahra, M.; Tamura, M. Estimation of leaf water status to monitor the risk of forest fires by using remotely sensed data. Remote Sens. Environ. 2004, 90, 441-450. 
29. Xiao, X.M.; Zhang, Q.Y.; Hollinger, D.; Aber, J.; Moore, B. Modeling gross primary production of an evergreen needleleaf forest using MODIS and climate data. Ecol. Appl. 2005, 15, 954-969.

30. Xiao, X.M.; Boles, S.; Liu, J.Y.; Zhuang, D.F.; Frolking, S.; Li, C.S.; Salas, W.; Moore, B. Mapping paddy rice agriculture in southern China using multi-temporal MODIS images. Remote Sens. Environ. 2005, 95, 480-492.

31. Boles, S.; Xiao, X.; Liu, J.; Zhang, Q.; Munkhtuya, S.; Chen, S.; Ojima, D. Land cover characterization of Temperate East Asia using multi-temporal VEGETATION sensor data. Remote Sens. Environ. 2004, 90, 477-489.

32. Sakamoto, T.; Van Nguyen, N.; Kotera, A.; Ohno, H.; Ishitsuka, N.; Yokozawa, M., Detecting temporal changes in the extent of annual flooding within the Cambodia and the Vietnamese Mekong Delta from MODIS time-series imagery. Remote Sens. Environ. 2007, 109, 295-313.

33. Delbart, N.; Kergoat, L.; Le Toan, T.; Lhermitte, J.; Picard, G. Determination of phenological dates in boreal regions using normalized difference water index. Remote Sens. Environ. 2005, 97, 26-38.

34. Delbart, N.; Le Toan, T.; Kergoat, L.; Fedotova, V. Remote sensing of spring phenology in boreal regions: a free of snow-effect method using NOAA-AVHRR and SPOT-VGT data (1982-2004). Remote Sens. Environ. 2006, 101, 52-62.

35. Xiao, X.M.; Zhang, Q.Y.; Saleska, S.; Hutyra, L.; De Camargo, P.; Wofsy, S.; Frolking, S.; Boles, S.; Keller, M.; Moore, B. Satellite-based modeling of gross primary production in a seasonally moist tropical evergreen forest. Remote Sens. Environ. 2005, 94, 105-122.

36. Mahadevan, P.; Wofsy, S.C.; Matross, D.M.; Xiao, X.M.; Dunn, A.L.; Lin, J.C.; Gerbig, C.; Munger, J.W.; Chow, V.Y.; Gottlieb, E.W. A satellite-based biosphere parameterization for net ecosystem CO2 exchange: Vegetation Photosynthesis and Respiration Model (VPRM). Global Biogeochem. Cycle 2008, 22, G01002, doi:10.1029/2006GB002735.

37. Xiao, X.M.; Zhang, Q.Y.; Braswell, B.; Urbanski, S.; Boles, S.; Wofsy, S.; Berrien, M.; Ojima, D. Modeling gross primary production of temperate deciduous broadleaf forest using satellite images and climate data. Remote Sens. Environ. 2004, 91, 256-270.

38. Wu, J.B.; Xiao, X.M.; Guan, D.X.; Shi, T.T.; Jin, C.J.; Han, S.J. Estimation of the gross primary production of an old-growth temperate mixed forest using eddy covariance and remote sensing. Int. J. Remote Sens. 2009, 30, 463-479.

39. Wu, W.; Wang, S.; Xiao, X.; Yu, G.; Fu, Y.; Li, Z.; Chen, B.; Song, T.; Hao, Y. Modeling gross primary production of a temperate grassland ecosystem in Inner Mongolia, China, using MODIS imagery and climate data. Sci. China Ser. D. 2008, 51, 1-12.

40. Yan, H.M.; Fu, Y.; Xiao, X.; Huang, H.; He, H.; Yu, G. Modeling gross primary productivity of winter wheat and maize double-cropping system, using MODIS time series imergy and CO2 eddy flux data. Agr. Ecosyst. Environ. 2009, 129, 391-400.

41. Xiao, X.M.; Boles, S.; Frolking, S.; Li, C.S.; Babu, J.Y.; Salas, W.; Moore, B. Mapping paddy rice agriculture in South and Southeast Asia using multi-temporal MODIS images. Remote Sens. Environ. 2006, 100, 95-113. 
42. Sims, D.A.; Rahman, A.F.; Cordova, V.D.; El-Masri, B.Z.; Baldocchi, D.D.; Bolstad, P.V.; Flanagan, L.B.; Goldstein, A.H.; Hollinger, D.Y.; Misson, L.; Monson, R.K.; Oechel, W.C.; Schmid, H.P.; Wofsy, S.C.; Xu, L. A new model of gross primary productivity for North American ecosystems based solely on the enhanced vegetation index and land surface temperature from MODIS. Remote Sens. Environ. 2008, 112, 1633-1646.

43. Sims, D.A.; Rahman, A.F.; Cordova, V.D.; El-Masri, B.Z.; Baldocchi, D.D.; Flanagan, L.B.; Goldstein, A.H.; Hollinger, D.Y.; Misson, L.; Monson, R.K.; Oechel, W.C.; Schmid, H.P.; Wofsy, S.C.; Xu, L.K. On the use of MODIS EVI to assess gross primary productivity of North American ecosystems. J. Geophys. Res-Biogeosci. 2006, 111, G04015, doi:10.1029/2006JG000162.

44. Xiao, X.M.; Hagen, S.; Zhang, Q.Y.; Keller, M.; Moore, B. Detecting leaf phenology of seasonally moist tropical forests in South America with multi-temporal MODIS images. Remotee Sens. Environ. 2006, 103, 465-473.

45. Mayaux, P.; Eva, H.; Gallego, J.; Strahler, A.H.; Herold, M.; Agrawal, S.; Naumov, S.; De Miranda, E.E.; Di Bella, C.M.; Ordoyne, C.; Kopin, Y.; Roy, P.S. Validation of the global land cover 2000 map. IEEE Tran. Geosci. Remot. Sen. 2006, 44, 1728-1739.

46. Strahler, A.; Muchoney, D.; Borak, J.; Friedl, M.; Lambin, E.F.; Moody, A. MODIS Land Cover Product Algorithm Theorectical Basis Document (ATBD), Version 5.0, MODIS Land Cover and Land-Cover Change; Department of Geography, Boston University: Boston, MA, USA, 1999; p. 66.

47. Herold, M.; Woodcock, C.E.; di Gregorio, A.; Mayaux, P.; Belward, A.S.; Latham, J.; Schmullius, C.C. A joint initiative for harmonization and validation of land cover datasets. IEEE Tran. Geosci. Remot. Sen. 2006, 44, 1719-1727.

48. Giri, C.; Zhu, Z.L.; Reed, B. A comparative analysis of the Global Land Cover 2000 and MODIS land cover data sets. Remote Sens. Environ. 2005, 94, 123-132.

49. Fritz, S.; Lee, L. Comparison of land cover maps using fuzzy agreement. Int. J. Geogr. Inf. Sci. 2005, 19, 787-807.

50. Loveland, T.R.; Reed, B.C.; Brown, J.F.; Ohlen, D.O.; Zhu, Z.; Yang, L.; Merchant, J.W. Development of a global land cover characteristics database and IGBP DISCover from $1 \mathrm{~km}$ AVHRR data. Int. J. Remote Sens. 2000, 21, 1303-1330.

51. Gilbert, M.; Xiao, X.M.; Pfeiffer, D.U.; Epprecht, M.; Boles, S.; Czarnecki, C.; Chaitaweesub, P.; Kalpravidh, W.; Minh, P.Q.; Otte, M.J.; Martin, V.; Slingenbergh, J. Mapping H5N1 highly pathogenic avian influenza risk in Southeast Asia. Proc. Nat. Acad. Sci. USA. 2008, 105, 4769-4774.

(C) 2009 by the authors; licensee Molecular Diversity Preservation International, Basel, Switzerland. This article is an open-access article distributed under the terms and conditions of the Creative Commons Attribution license (http://creativecommons.org/licenses/by/3.0/). 